Grzegorz Łukomski

(Uniwersytet im. Adama Mickiewicza w Poznaniu, Instytut Kultury Europejskiej w Gnieźnie) prof. dr hab., grzegorzlukomski@op.pl

\title{
Ententa i Niemcy wobec polskiej polityki wschodniej 1918-1919
}

\begin{abstract}
Wstęp
Pozytywny wpływ Ententy na restytucję polskiej państwowości - wbrew licznym naukowym i potocznym opiniom - to mit. W rzeczywistości był ów wpływ nader ograniczony i w dużej mierze wymuszony biegiem wydarzeń, a wielokrotnie wręcz destrukcyjny. Stwierdzić należy zdecydowanie, iż Rzeczpospolita uformowała się przede wszystkim na drodze faktów dokonanych, w wyniku spontanicznego działania narodu, lecz i w wyniku rozsądnego oraz zaangażowanego działania znaczącej części jego elit politycznych. Spiritus movens ówczesnych wydarzeń, pośród licznego grona wskrzesicieli państwa, byli szczególnie dwaj Polacy, Józef Piłsudski i Roman Dmowski. O ile zainteresowanie aliantów i Niemców polskimi aspiracjami wobec kresów zachodnich jest znane i adekwatnie opisane w historiografii, o tyle kwestia wschodnich obszarów Rzeczypospolitej oraz zwłaszcza granicy wschodniej państwa była bardziej subtelna politycznie i militarnie, a stosunek do niej Ententy i Niemiec bywał dotąd - z różnych powodów - interpretowany w literaturze przedmiotu nader bałamutnie oraz jednostronnie.
\end{abstract}

\section{Alianci wobec restytucji Rzeczypospolitej}

Spójrzmy zatem na fakty. W traktacie rozejmowym z 11 listopada $1918 \mathrm{r}$. Polska nie została w ogóle wymieniona. W tekście tego aktu prawnego nie było żadnego postanowienia, dotyczącego przyszłości zachodnich obszarów kraju, na których nadal miały pozostać wojska niemieckie. Obowiązywały 
nadal granice z 1914 r. A działał przecież aktywnie w Paryżu uznawany przez aliantów Komitet Narodowy Polski pod przywództwem wielce zasłużonego i kompetentnego Romana Dmowskiego.

Józef Piłsudski ujął sprawę adekwatnie, mówiąc: „[...] Pamiętam, gdym jeszcze w Magdeburgu [w czasie internowania - G.Ł.] czytał warunki zawieszenia broni, z wielkim przerażeniem stwierdziłem, że Polska jest w tym zawieszeniu pominięta i że pozostaje na razie w tych samych warunkach $[\ldots]^{\prime \prime}$. Nie było to przypadkowe. Krajom anglosaskim, Wielkiej Brytanii i Stanom Zjednoczonym - wbrew intencjom francuskim - bardzo zależało na pozostawieniu spraw polskich możliwie długo otwartymi, znajdującymi się w politycznym zawieszeniu, w oczekiwaniu na wyjaśnienie sytuacji w zrewolucjonizowanej Rosji. Ponadto pomiędzy Brytyjczykami i Francuzami istniała zasadnicza różnica zdań na kwestię polską. Francja dążyła do restytucji Polski stosunkowo silnej, lecz wzmocnionej terytorialnie jedynie kosztem Niemiec, mającej być skuteczną zaporą przeciw ewentualnym przyszłym ekspansywnym działaniom tego państwa. Zdecydowanie jednak nie zamierzała uszczuplać terytorium byłego carskiego imperium, z którym wiązały ją rozległe interesy ekonomiczne. Wielka Brytania natomiast, w obawie przed wzrostem wpływów francuskich, zmierzała do zachowania możliwie silnych Niemiec, a jej celem strategicznym, podobnie jak Francji, także były niezmierzone bogactwa Rosji. Lord Arthur J. Balfour, minister spraw zagranicznych Wielkiej Brytanii, w memoriale z 4 października 1916 r. postulował "utworzenie Polski wyposażonej w szeroką autonomię, ale pozostającej integralną częścią Imperium Rosyjskiego" ${ }^{2}$. W mentalności polityków zachodnich $\mathrm{z}$ wielkim trudem znajdowała sobie miejsce myśl związana $\mathrm{z}$ restytucją prawdziwie niepodległej Polski.

Uważany później na konferencji pokojowej - nie bez racji - za sprzyjającego interesom Polski pułkownik Edward M. House, bliski wieloletni doradca i osobisty sekretarz prezydenta Thomasa W. Wilsona, także początkowo skwapliwie popierał postulaty brytyjskie. Już tekst układu w Compiêgne, narzuconego wówczas Niemcom, zawierał konstatacje potencjalnie dla Polski bardzo niebezpieczne. Wprawdzie klęska wojenna Niemiec na zachodzie była zupełna i nie budziła wśród aliantów wątpliwości (zupełne inaczej twierdzili Niemcy, o czym warto pamiętać), lecz odmiennie przedstawiała się sytuacja militarna na wschodzie kontynentu. Tu siła Niemiec była jeszcze znacząca i bez wątpienia stanowiły one jedyną w tym regionie liczącą się potęgę woj-

${ }^{1}$ J. Piłsudski, Pisma zbiorowe, Wydanie prac dotychczas drukiem ogłoszonych, t. 5, Warszawa 1937, s. 231. Przemówienie wygłoszone 27 grudnia 1921 r. w Poznaniu z okazji trzeciej rocznicy wybuchu powstania wielkopolskiego.

${ }^{2}$ K. Okulicz, Brzask, dzień i zmierzch na ziemiach Litwy Historycznej, [w:] Pamiętnik Wileński, Londyn 1972, s. 56-57. 
skową. Układ rozejmowy z 11 listopada zmuszał co prawda wojska niemieckie do wyrzeczenia się traktatu brzeskiego z 3 marca 1918 r., opuszczenia zajętych obszarów i cofnięcia się do granic z 1914 r. $^{3}$ Jednakże „przy wzięciu pod uwagę sytuacji wewnętrznej tych terytoriów". Chodziło oczywiście o zapobieżenie sytuacji, w której na opuszczonych przez Niemców obszarach mogła wytworzyć się militarna i polityczna próżnia, z której skorzystaliby bolszewicy. Stworzyło to Niemcom olbrzymie i niezwykle dogodne pole manewru, $\mathrm{z}$ jednej strony występowali $\mathrm{w}$ dalszym ciągu, mimo poniesionej klęski, w roli obrońcy porządku i zachodniego ładu cywilizacyjnego przed bolszewikami, a z drugiej - utorowało to drogę do współpracy niemiecko-bolszewickiej Wynikało z tego później szereg trudności i problemów, zwłaszcza w krajach bałtyckich, lecz także na ziemiach polskich, i w oczywisty sposób wzmocniło tam pozycję Niemiec.

Kolejną niebezpieczną dla Polski tendencją lansowaną przez anglo-amerykańską część Ententy, a szczególnie przez Brytyjczyków (lord Arthur J. Balfour) już na etapie przygotowań do układu rozejmowego, było domaganie się dla niej granic etnicznych, zdecydowanie odbiegających od granic historycznych z 1772 r., a wypowiedzi związane z dostępem kraju do morza też były kuriozalnie, wręcz enigmatyczne ${ }^{5}$. Brytyjczycy, kierując się swoimi imperialnymi interesami, i mający - na co warto zwrócić uwagę - mentalność, którą można określić jako „kolonialną”, w Europie także wprawdzie o nie zabiegali, lecz jednocześnie pozostali wierni swojej realizowanej od XVIII w. polityce "równowagi sił” na Starym Kontynencie. Odnosili się z rezerwą do postulatów polskich i dalecy byli od zaangażowania się na rzecz granic przyszłego państwa polskiego. Polskę zaliczali do szeregu "małych” państw, które uważali za "satelity" Francji. Notabene, po podpisaniu traktatu pokojowego Niemcy, niezadowoleni z narzuconych sobie ograniczeń i w poczuciu klęski, ochoczo podjęli ten wątek propagandowy, nazywając Polskę „kreaturą Francji” i „państwem sezonowym” (Saisonsstaat) ${ }^{6}$. Ambicje polityczne małych państw wydawały im się wręcz "nikczemne” (miserable), powinny one bowiem zaufać "wielkim” i zadowolić się tym, co z ich łaski otrzymają7. Było to proste nawiązanie do instytucji „koncertu mocarstw”, istniejącej w polity-

\footnotetext{
${ }^{3}$ Nakaz opuszczenia przez wojska niemieckie jedynie ziem okupowanych przez nie w czasie wojny nie stwarzał takiego obowiązku na ziemiach byłego zaboru pruskiego. T. Komarnicki, Pitsudski a polityka wielkich mocarstw, „Niepodległość” Londyn 1952, t. 4 (po wznowieniu), s. 20; G. Łukomski, Problem „korytarza” w stosunkach polsko-niemieckich i na arenie międzynarodowej 19191939. Studium polityczne, Warszawa 2000, s. 25-26.

${ }^{4}$ G. Łukomski, dz. cyt., s. 41-78.

${ }^{5}$ T. Komarnicki, dz. cyt., s. 21-22.

${ }^{6}$ G. Łukomski, dz. cyt., s. 40-41.

7 T. Komarnicki, dz. cyt., s. 34 .
} 
ce europejskiej od 1815 r. (wówczas były to: Wielka Brytania, Rosja, Austria i Prusy).

Paryska konferencja pokojowa (18 stycznia - 28 czerwca 1919 r.) była właśnie takim „koncertem mocarstw”, o zmienionym wprawdzie i nieco rozszerzonym składzie w porównaniu do tego pierwszego. W praktyce chodziło nie tylko o problem zagrożenia bolszewickiego i możliwych generalnych zmian na obszarze Europy Wschodniej (przede wszystkim bardzo ważnych - ekonomicznych), lecz też o to, by nadmiernie nie osłabiać Niemiec na korzyść Francji. Brytyjski premier David Lloyd George kierował się przede wszystkim troską o to, by Francja nie zyskała zbyt dużo w porównaniu z Brytyjczykami oraz by powstał taki traktat pokojowy, który Niemcy chcieliby podpisać. Nie ukrywał też, że sprawa polska była w czasie obrad konferencji pewnym nader kłopotliwym problemem.

Odmienne w porównaniu z Londynem były działania polityki i dyplomacji francuskiej. W ogólności dla Polski pozytywne, wręcz nie do przecenienia. Francja wspierała Polskę jako potencjalną zaporę przeciwko bolszewickiej Rosji czy wręcz siłę uczestniczącą w pokonaniu bolszewizmu i przewrócenie w Rosji status quo ante. Polska miała zatem poparcie wojskowe przeciwko Rosji w zakresie walki z bolszewizmem, lecz nie było wspólnych celów politycznych. Natomiast popieranie „białych" Rosjan zupełnie nie leżało w interesie odradzającej się Polski. Ponadto Rzeczpospolita była również dogodnym partnerem i sojusznikiem przeciw Niemcom, wprawdzie pokonanym, lecz zawsze antagonistycznym i niebezpiecznym. Rząd francuski, a nade wszystko prezydent republiki Raymond Poincaré, rozsądny, o przekonaniach prawicowych, oraz zdecydowanie antyniemiecki premier Georges Clemenceau, $\mathrm{w}$ trosce bowiem o francuską rację stanu dążyli nie tylko do restytucji Polski jako bytu politycznego, lecz i do odtworzenia status quo ante, sięgając do okresu sprzed rozbiorów. Chodziło o nadanie Polsce takiego znaczenia, aby stała się wsparciem dla francuskiej polityki na wschodzie kontynentu. Jednak co ważne - pod kuratelą Paryża, nie zaś obok czy wbrew intencjom Francji ${ }^{8}$. Francuzi jako jedyni wśród państw sprzymierzonych mieli jakąś wizję przebudowy środkowej i wschodniej Europy.

Ponadto wielką część ówczesnej sytuacji politycznej stanowił problem rosyjski, mimo iż formalnie Rosja jako państwo nie była uczestnikiem konferencji w Paryżu. Miała jednak nad Sekwaną swoje dość opiniotwórcze przedstawicielstwo. Mocarstwa mające decydujący wpływ w czasie rokowań pokojowych dążyły do zachowania swoich wpływów w Rosji, gdyż gra była tego warta. Pragnęły zachować je także w nowych, bolszewickich czy też innych realiach politycznych na obszarze byłego Cesarstwa Rosyjskiego. Dlatego właśnie niechętnie widziały samodzielne inicjatywy Polski na wscho-

\footnotetext{
${ }^{8}$ G. Łukomski, dz. cyt., s. 23-41.
} 
dzie Europy. Zwrócić należy uwagę na fakt, iż już 23 grudnia 1917 r., a więc w kilka tygodni po przewrocie bolszewickim, Francja i Wielka Brytania podpisały konwencję wojskowo-polityczną. Dzieliła ona terytorium rosyjskie na strefy wpływów. Strefa francuska obejmowała: Besarabię, Ukrainę i Krym, a brytyjska: Kaukaz, Armenię, Gruzję, lecz także Rosję Północną, włącznie z krajami bałtyckimi. Obszar byłego Wielkiego Księstwa Litewskiego znalazł się zatem w orbicie zainteresowań brytyjskich. Fakt ten miał doniosłe znaczenie dla przebiegu wydarzeń $\mathrm{w}$ tym regionie. Polska, podejmując tam działania, wkraczała w domenę Brytyjczyków ${ }^{9}$.

Paryska konferencja była więc wielkim polem ścierania się interesów oraz poglądów, lecz i ataków ze strony aliantów, głównie Brytyjczyków, na polską politykę wschodnią. Duża rola przypadła wówczas Ignacemu Paderewskiemu. Premier-artysta, choć pełen szczerych chęci i zapału, nie zawsze dobrze czuł się w środowisku politycznym, właściwie dla niego obcym, a przez niektórych polityków uważany był nawet za „ignoranta”. Był idealistą wśród twardych, doświadczonych, niecofających się przed obcesowymi, często prostackimi filipikami i działaniami. Ustępował też doświadczeniem politycznym. Stał się jednak godnym reprezentantem Polski i adwokatem sprawy polskiej. Miał zatem zadanie o wiele trudniejsze niż jego partnerzy. Przyciągał natomiast inteligencją i kulturą osobistą. Uwidoczniło się to już w czasie krótkiego pobytu nad Sekwaną, od 5 kwietnia 1919 r., jeszcze przed podpisaniem traktatu pokojowego. W czasie spotkań oficjalnych i kuluarowych podkreślał wagę kwestii terytorialnych. Dla urodzonego na Podolu premiera Rzeczypospolitej, słowo „Polska” miało naturalną, historyczną perspektywę i kojarzyło się z państwem sprzed pierwszego rozbioru. W czasie jednego ze spotkań doszło do znamiennego incydentu, konfrontacji z premierem Wielkiej Brytanii. Lloyd George zarzucił Paderewskiemu „imperializm” poglądów. Zabrzmiało to co najmniej niestosowanie w ustach przywódcy największego wówczas światowego imperium kolonialnego. Paderewski zareagował zdecydowanym responsem. „,...] Nie jesteśmy imperialistami i nie chcemy anektować żadnego kraju ani żadnego narodu. Nigdy nie prześladowaliśmy żadnej religii. Nigdy nie narzucaliśmy innym obcych im obyczajów, czego najlepszym dowodem jest fakt, że po 600 latach wspólnego życia prymitywne narody, takie jak Litwini, Białorusini czy nawet Ukraińcy, nadal istnieją i przy naszej praktycznej nawet pomocy odzyskują swój indywidualny charakter $[\ldots]^{\prime \prime}$.

${ }^{9}$ T. Komarnicki, dz. cyt., s. 34-35.

${ }^{10}$ Cyt. za: W. Sukiennicki, Polityczne konsekwencje błędu semantycznego, "Zeszyty Historyczne", Paryż 1985, z. 72, s. 32. Wiktor Sukiennicki (1901-1983), prawnik, historyk, politolog; w latach trzydziestych w Wilnie docent na Wydziale Prawa Uniwersytetu Stefana Batorego (USB) oraz pracownik Instytutu Europy Wschodniej; w 1941 r. więzień łagru NKWD; z Sowietów wyszedł wraz z Armią gen. Władysława Andersa; od 1943 r. w Anglii; od 1959 r. w Stanach 
Był też - co warto podkreślić - swoistym pośrednikiem pomiędzy ambicjami politycznymi wielkich rywali, Piłsudskiego i Dmowskiego. Po raz kolejny przebywał we Francji na przełomie czerwca i lipca, z okazji podpisania traktatu wersalskiego (28 czerwca).

Na tle wypowiedzi Lloyda George’a powstała propagandowa teza o „imperializmie polskim" w ówczesnych relacjach z Rosją bolszewicką. Bazowano na ignorancji społecznej, braku elementarnej wiedzy na ten temat, co w połączeniu ze złą wolą i tendencyjnością panującą wśród niektórych środowisk zachodnioeuropejskich przyniosło Polsce wiele strat. Upowszechniła ją propaganda rosyjska, zarówno „czerwona”, jak i „biała”. Jak zauważyła Anna Cienciała, teza znalazła swoje miejsce w polskim konflikcie wewnętrznym pomiędzy zwolennikami Piłsudskiego a narodowymi demokratami. Zaczęto wypominać sobie wzajemnie: „krótkowzroczność” z jednej strony, „,komiwojażerstwo" i „,awanturnictwo" - z drugiej strony. Jednak szczególnie wygoda, a nawet funkcjonalna, okazała się dla komunistów, w przekazie medialnym, lecz - co gorsza - także naukowym. Upowszechniła się w Europie w zakresie potocznego rozumienia wydarzeń lat 1918-1920. Promowana jest, wcale nierzadko, także współcześnie ${ }^{11}$.

\section{Niemiecka Ostpolitik}

Niemcy istotnie przejawiały $\mathrm{w}$ czasie Wielkiej Wojny wiele aktywności $\mathrm{w}$ kwestii bałtyckiej, a elementy tej polityki w zakresie formowania tzw. państw buforowych (Randstaatenpolitik) obowiązywała przez cały rok $1919^{12}$. Zwycięstwa niemieckie na wschodzie Europy, w wyniku których zajęto duże obszary ziem nadbałtyckich, wzmocniły dążenia aneksjonistyczne. System "państw buforowych" rozciągać się miał nie tylko we wschodniej części kontynentu. Państwom tym zamierzano przyznać pewne znamiona suwerenności. Problemem zainteresowane były nie tylko sfery wojskowo-przemysłowe, lecz także kręgi uczonych oraz intelektualistów ${ }^{13}$. Jeszcze w czasie trwania

Zjednoczonych (Instytut Hoovera przy uniwersytecie w Stanford w Kalifornii); współpracownik paryskiej „Kultury”; autor licznych prac z zakresu dziejów Europy Środkowej i Wschodniej, szczególnie obszaru byłego Wielkiego Księstwa Litewskiego. Zmarł w Kalifornii w Mountains View. Zob. Cz. Miłosz, Szukanie ojczyzny, Kraków 2001, s. 259.

${ }^{11}$ A. Cienciała, Stosunki polsko-sowieckie - federalizm - polityka polska - 1914-1921, „Zeszyty Historyczne" , Paryż, 1970, z. 18, s. 215.

12 P. Łossowski, Między wojna a pokojem. Niemieckie zamysty wojenne na wschodzie w obliczu traktatu wersalskiego, marzec-czerwiec 1919 roku, Warszawa 1876, s. 54-57; K. Lundgreen-Nielsen, The Polish Problem at the Paris Peace Conference. A Study of Policies of the Great Powers and the Poles, 1918-1919, przekł. A. Borch-Johansen, Odense University Press 1979, s. 125-162.

${ }^{13}$ Pisał na ten temat m. in. badacz dziejów najnowszych Erich Brandenburg, Deutschlands Kreiegsziele, Leipzig 1917, s. 7-13, 41-44. 
Wielkiej Wojny przygotowywano intelektualno-teoretyczne podstawy dla kontynuowania niemieckiego Drang nach Osten, zwłaszcza w tzw. uniwersytetach wschodnich, do których zaliczano uczelnie we Wrocławiu, Berlinie, Greifswaldzie i Królewcu ${ }^{14}$.

Swoją koncepcję wschodnią Niemcy realizowali dość konsekwentnie i początkowo - z niemałym powodzeniem. Podobne jak na ziemiach Królestwa Polskiego, działania o charakterze politycznym i administracyjnym zastosowali na obszarze byłego Wielkiego Księstwa Litewskiego.

W wyniku niepowodzeń wojennych armii rosyjskiej od września 1915 r. tereny Litwy Kowieńskiej, Wileńszczyzny oraz Białorusi znalazły się pod okupacją niemiecką. Fakt ten wytworzył zupełnie nową konfigurację polityczną i militarną. Utworzono administrację wojskową (Militärverwaltung Oberbefehlshaber Ost), obejmującą pięć okręgów (Litwa, Suwałki, Wilno, Grodno, Białystok), później stopniowo połączonych i nazwanych Militärverwaltung Litauen. A zatem dowództwo Ober-Ostu, tak w skrócie określano obszar okupacji niemieckiej, sprawowało na obszarze okupowanym niepodzielną władzę administracyjną. Bazą kolonizacji i germanizacji Wschodu miała być Kurlandia, zdominowana przez niemiecką wielką własność ziemską, oraz Litwa (projekt Taryba). Z tego założenia wynikały późniejsze niemieckie zabiegi zmierzające do politycznej i militarnej na tym terenie dominacji, nawet po podpisaniu rozejmu na froncie zachodnim, w listopadzie $1918 \mathrm{r}$.

Niemieckie elity polityczne zdawały sobie sprawę z zasadniczych ograniczeń ekonomicznych państwa. Niemcy nie były w stanie prowadzić dłużej trwającej wojny bez zaplecza demograficznego i surowcowego Europy Środkowej i Południowej. Powstała wówczas wspomniana już specyficzna koncepcja, którą nazwano Mitteleuropa (Europa Środkowa), rozwijana w cesarstwie teoretycznie od przełomu wieków, a zastosowana w praktyce w czasie Wielkiej Wojny 1914-1918. Głoszona przez ideologów i polityków niemieckich, miała bardzo istotne znaczenie, dotyczyła stworzenia zdominowanego przez Niemcy obszaru gospodarczego i geopolitycznego. Pojawiła się u schyłku XIX w., a szczególne uznanie znalazła w czasie Wielkiej Wojny. Jej idee propagował m.in. Friedrich Naumann w wydanej pod tym samym tytułem pracy (1915 r.). Próbowano tworzyć uzależnione od Niemiec państewka białoruskie, litewskie, polskie, ukraińskie etc.

W debatę publiczną na ten temat zaangażowana była duża część niemieckich elit politycznych, zdumiewająco duża. Już wówczas tworzono podsta-

${ }^{14}$ E. Ruecker, T. Marski, Instytuty naukowe w Niemczech w stużbie propagandy, [w:] Przeciw propagandzie korytarzowej, red. J. Borowik, Torun 1930, s. 131; por.: B. Piotrowski, Badania nad Polską i krajami nadbałtyckimi na Uniwersytecie Królewieckim (1916-1932), „Komunikaty Instytutu Bałtyckiego" Gdańsk 1983, z. 35, s. 93-97. 
wy koncepcji kolonizacji wschodniej Europy po Dniepr i Dźwinę. Rosję natomiast zamierzano zepchnąć do Azji. Pisał na ten temat m.in. Adolf Bartels, niemiecki pisarz i historyk literatury. Ludność tych obszarów natomiast proponował "przesiedlić” i stworzyć dla niej „rezerwaty”. Z kolei inny autor, Paul Rohrbach, urodzony w Kurlandii publicysta polityczny, aktywnie wspierał niemiecką Ostpolitik swoją bogatą twórczością i działalnością polityczną na terenie Wielkiego Księstwa Litewskiego. Był propagatorem „wielkich Niemiec", mocarstwowości i globalnej polityki niemieckiej, jako światowego gracza polityczno-militarnego. Promował także w swych pracach politykę kolonialną Niemiec. Inspirację stanowiły doświadczenia europejskich kolonizatorów, Brytyjczyków, Francuzów etc., poza Starym Kontynentem. Spośród licznych i obszernych prac wymienić należy chociażby: Das Baltenbuch. Die baltischen Provinzen und ihre deutsche Kultur (1916); Der Krieg und deutsche Politik (1915) $)^{15}$.

Plany te znalazły później wyraz w podyktowanych przez Niemcy i Austro-Węgry (1918 r.) traktatach brzeskim i bukareszteńskiem. W rezultacie miał powstać satelicki związek oderwanych od Rosji państw - od Finlandii, poprzez kraje bałtyckie, Polskę, Ukrainę, aż do Kaukazu. Działania te, których celem było ekonomiczne i polityczne zdominowanie wschodu Europy, miały swoją podbudowę ideologiczną związaną z geopolityką, nowym kierunkiem badań naukowych, często pseudonaukowych, a także sposobem praktycznego myślenia politycznego. Dla Niemiec możliwe było istnienie Polski jedynie jako państwa buforowego, kadłubowego i niesuwerennego, które byłoby łatwym terenem penetracji i eksploatacji. Do koncepcji tej powrócono w czasie drugiej wojny światowej, tworząc byt polityczny o nazwie Generalne Gubernatorstwo. Był to zatem ciągle ten sam obszar terytorium Rzeczypospolitej, który w przybliżeniu odpowiadał Królestwu Polskiemu, wykreowanemu na kongresie wiedeńskim w 1815 r. ${ }^{16}$

\section{Piłsudski i Dmowski}

Całokształt sytuacji geopolitycznej najlepiej spośród polskich polityków bez wątpienia rozumiał Józef Piłsudski, chociaż i jego wizja była niekiedy nazbyt wyidealizowana. Kwintesencję sytuacji, w jakiej znalazła się Polska, oraz wy-

${ }^{15}$ W. Sukiennicki, East Central Europe during World War I: from Foreign Domination to National Independence, vol. I, New York 1984, s. 139-142.

${ }^{16}$ Opublikowano wówczas niewielkiej objętości książkę F. Naumanna, Mitteleuropa, Berlin, październik 1915, przedstawiającą jednak niezwykle ważkie treści, kompleksowy program Związku Środkowoeuropejskiego pod egidą Niemiec. Por.: G. Łukomski, Polityczna przestrzeń polskości w XX wieku Bezpieczeństwo polityczne Rzeczypospolitej z perspektywy racji stanu, PoznańLondyn 2013, s. 12-13, 29-30, 125. 
nikającą z niej pozorną dwoistość polityki zagranicznej najlepiej wyjaśnia jego uwaga wypowiedziana podczas rozmowy z Władysławem Baranowskim (7 lutego 1919 r.), delegatem Naczelnika Państwa w paryskim Komitecie Narodowym: „[...] w tej chwili Polska jest właściwie bez granic i wszystko co możemy w tej mierze zdobyć na zachodzie - mówił Piłsudski - zależy od Ententy, o ile ona mniej lub więcej ścisnąć Niemcy. Na wschodzie to inna sprawa, [...] tu są drzwi, które się otwierają i zamykają i zależy kto i jak szeroko siłą je otworzy [...]"17. Naczelnik Państwa doskonale zdawał sobie sprawę z tego, iż określenie polskich granic zachodnich zależało wyłącznie od Ententy, a zatem pośrednio od działań Komitetu Narodowego Polskiego. Sam zaś nie miał na paryskie decyzje podejmowane podczas konferencji pokojowej żadnego wpływu. Natomiast na wschodzie zdecydowany był realizować własne cele polityczne, niezależnie od stanowiska Ententy, w praktyce często wbrew jej intencjom i zamiarom.

Pozycja Piłsudskiego wobec państw sprzymierzonych była trudna i - przyznajmy - słaba, przede wszystkim z tego powodu, że przejął władzę w wyniku spontanicznych wydarzeń społecznych, nie zaś z nadania aliantów. Nie budziły też zaufania na Zachodzie jego niegdysiejsze fascynacje ruchem socjalistycznym, a nade wszystko opowiedzenie się w czasie wojny po stronie państw centralnych (Legiony, jak wiadomo, organizował na terenie Austro-Węgier). Dobre relacje z państwami Ententy wypracował tymczasem Roman Dmowski, wielki rywal polityczny Piłsudskiego, i miał w tym zakresie pozycję monopolistyczną. W odróżnieniu od Piłsudskiego, jak wspomniano - „człowieka czynu", był myślicielem, intelektualistą. Zwolennik państwa narodowego, a w kwestii Kresów Wschodnich koncepcji inkorporacyjnej. Natomiast na konferencji pokojowej prezentował, jako jej współtwórca, polską myśl zachodnią, ideologię zachodnią. Swoją pozycję na zachodzie Europy wykorzystał, aktywnie zabiegając o uznanie KNP jako rządu polskiego. Zgodę taką wyraziła już 15 listopada 1918 r. Francja, lecz negatywnie odniosły się do niej, w sensie formalnym, rządy Wielkiej Brytanii, Włoch i Stanów Zjednoczonych, mimo wniosku KNP, biorąc pod uwagę fakty, które dokonały się w kraju ${ }^{18}$.

Federacyjnej koncepcji Piłsudskiego narodowi demokraci z Romanem Dmowskim przeciwstawiali uwarunkowania historyczno-etniczne (najogólniej była to koncepcja inkorporacyjna). Pomimo wielu zastrzeżeń, skłaniał się ku niej także Ignacy Paderewski. Swoje kalkulacje opierał Dmowski o wizję „Wielkiej Polski”, mówiono też mocarstwowej, oczywiście tylko w kontekście koncertu państw europejskich. Sądził, iż zdoła taką pozycję wynegocjować przy poparciu Francji. Nie wziął jednak pod uwagę faktu, iż pozycja Francji słabła systematycznie na korzyść Brytyjczyków i Amerykanów. Punktem wyj-

17 W. Baranowski, Rozmowy z Piłsudskim 1916-1931, Warszawa 1938, s. 64.

${ }^{18}$ T. Komarnicki, dz. cyt., s. 22. 
ścia była oczywiście granica sprzed pierwszego rozbioru (1772 r.), z uwzględnieniem zmian etniczno-ekonomicznych, które zaszły w ciągu XIX w. Był zdania, że mocarstwa zachodnie potrzebują silnej Polski jako partnera politycznego, bardziej niż słabej, którą trzeba będzie wspierać. Miała to być Polska stanowiąca naturalną zaporę przeciwko niestabilnej sytuacji w Rosji bolszewickiej z jednej strony, oraz będąca przeciwwagą dla Niemiec - z drugiej. Dmowski już w czasie Wielkiej Wojny wytrwale zabiegał w stolicach zachodnioeuropejskich oraz w Stanach Zjednoczonych o zrozumienie dla programu terytorialnego postulowanego przez siebie oraz obóz polityczny, którego był przedstawicielem ${ }^{19}$.

Dmowski posiadał jednak pewną ułomność, która negatywnie wpływała od odbiór jego przekazu politycznego. Bywał niekiedy zbyt otwarty w wyrażaniu swoich poglądów, co z pewnością nie jednało mu zwolenników. Przed Piłsudskim stanęło zatem wielkie zadanie ułożenia takich relacji z KNP, które nie tylko zapewniłyby samodzielność polskiej polityki, lecz i stworzyły jednolity front polskich działań dyplomatycznych na zewnątrz. Jakiekolwiek nieporozumienia wśród najwyższych przedstawicieli polskich elit politycznych zostałyby z pewnością wykorzystane przez przeciwników i rywali, a także przez partnerów politycznych.

Dmowski i Piłsudski wyciągnęli do siebie dłonie. Uzupełniali się bowiem doskonale i byli sobie potrzebni. Do kompromisu doprowadziła misja Stanisława Grabskiego (przebywał w Warszawie od 5 do 12 grudnia 1918 r.), członka KNP. Konsensus nastąpił także w sprawach szczegółowych, zwłaszcza w kwestii przyszłych polskich granic państwowych. Zgodzono się wówczas na wschodnią granicę wzdłuż Berezyny, Słuczy, Horynia i Uszycy. Było to ważne, gdyż dążenia narodowych demokratów do stworzenia państwa narodowego, możliwie jednolitego etnicznie, prowadziły w konsekwencji do polityki inkorporacyjnej na Kresach Wschodnich. Zderzały się one z planami federacyjnymi Piłsudskiego. Paradoksalnie jednak, w czasie rozmów w Belwederze - jak zanotował Michał Sokolnicki: „[...] imperializm Komendanta idzie dalej, szczególnie co się tyczy granicy wschodniej białoruskiej, starając się w całości przy Państwie Polskim ją zostawić [...]"20. Paradoks był pozorny. Naczelnik miał oczywiście na uwadze zachowanie możliwie w całości obszaru byłego Wielkiego Księstwa Litewskiego.

Z powyższego politycznego kontekstu wziął się wielokrotnie w literaturze przywoływany list Naczelnika do Dmowskiego z 21 grudnia 1918 r.: „[...] Niech mi Pan wierzy - pisał - że nade wszystko życzę sobie uniknięcia podwójnego przedstawicielstwa Polski wobec aliantów; tylko jedno wspól-

${ }^{19}$ R. Dmowski, Polityka polska i odbudowanie państwa, t. 2, Warszawa 1988, s. 124-128, 309; J. Karski, Wielkie mocarstwa wobec Polski 1919-1945. Od Wersalu do Jatty, Lublin 1998, s. 35-44.

${ }^{20}$ M. Sokolnicki, W stużbie Komendanta, „Kultura” Paryż 1953, nr 74, s. 81. 
ne przedstawicielstwo może sprawić, że nasze żądania zostaną wysłuchane [...]"21. Politycy zaczęli ze sobą współpracować. Chwila była ważna, prawdziwie dziejowa, a dla nich niełatwa. Przechodząc do porządku nad faktem, iż pole manewru mieli niewielkie, przyznać trzeba, że obaj wznieśli się wówczas właśnie, wprawdzie na niedługi czas, na wyżyny mężów stanu. W rezultacie zyskała sprawa polska.

Czy jednak obaj mężowie stanu mogli zawrzeć trwały konsensus? Przenikliwy i kompetentny, znający bowiem doskonale ówczesne stosunki i ludzi tworzących wówczas politykę, Stanisław Cat-Mackiewicz ${ }^{22}$ słusznie skonstatował, że obaj byli genialni, a dla dwóch tak wielkich nie było wówczas w Polsce miejsca. „[...] Piłsudski nie miał żadnych zastrzeżeń personalnych, nikomu nie chciał pamiętać i istotnie nie pamiętał przeszłości, gotów był do każdego rękę wyciągnąć kto by go chciał uznać za leadera i współpracować w ramach jego ideałów politycznych. Niewątpliwie współpracowałby z Dmowskim. Ale to było niemożliwe. Nie pomniejsza to w niczym osoby Dmowskiego. Nie chodziło tu przecież o sprawy osobiste [rywalizacja Piłsudskiego i Dmowskiego o względy Marii Juszkiewiczowej, przegrana przez Dmowskiego - G.Ł.], lecz o ideowe. Dmowski miał na szereg spraw zapatrywania wręcz odmienne od Piłsudskiego, i to tak dalece odmienne, że kompromis był niemożliwy [...]"23.

Podkreślić należy, iż Dmowski niewątpliwie nie chciał wyrzekać się ziem polskich z ludnością niepolską lub mieszaną, nie chciał jej odtrącać czy wykluczać, chciał tę ludność zintegrować z kulturą polską, zasymilować. Dążył do jej polonizacji, podobnie jak niegdyś spolonizowała się szlachta litewsko-ruska. Pośród wielu zasług tego męża stanu jedną z największych było to, iż zdefiniował na nowo pojęcie narodu. Wynikała z owej definicji pewna ważna konstatacja. Uważał, a była to konstatacja nader słuszna, że „nie naród tworzy państwo, lecz państwo tworzy naród”. Społeczność, trwając przez pokolenia na tym samym obszarze, integruje się, konsoliduje i wytwarza wspólną kulturę oraz więzi emocjonalne. Przekształca się w naród. Pogląd taki wyraził już na początku XX w., gdy odrodzona Rzeczpospolita była jedynie mglistym bytem snującym się w opłotkach wielkiej polityki europejskiej. Wyartykułował myśl wydawałoby się oczywistą, a tym bardziej w polskich realiach poroz-

${ }^{21}$ J. Piłsudski, Pisma, t. 5, s. 45-46.

${ }^{22}$ Stanisław Cat-Mackiewicz od sierpnia 1922 r. prowadził znane później i opiniotwórcze "Słowo", finansowane przez konserwatystów wileńskich. Jak wspomina ksiądz Walerian Meysztowicz: „[...] byłem wraz z Jasiem Tyszkiewiczem jednym z tych, którzy zaproponowali memu ojcu [Aleksandrowi Meysztowiczowi - G.Ł.] Stasia Mackiewicza. Zapewniał nas o swym katolicyzmie. Stąd jego pseudonim »Cat« (potem najrozmaiciej wykładany [...]". W. Meysztowicz, Gawędy o czasach i ludziach, Londyn 1993, wyd. IV, s. 227-228.

23 S. Mackiewicz (Cat), Historia Polski od 11 listopada 1918 r. do 17 września 1939 r., Warszawa 1989, s. 85. 
biorowych, mającą swój głęboki sens. „[...] Państwo polskie - pisał - stworzy przede wszystkim naród polski, z rdzennie polskiej ludności złożony, polską żyjący kulturą; gdy zdobędzie odpowiednią siłę wewnątrz i na zewnątrz, wtedy w odpowiedniej chwili może jednać sobie koncesjami tych, których będzie potrzebował $[\ldots]^{\prime 24}$.

Ponadto federacyjne "pomysły" Piłsudskiego uważał za "niedorzeczne”. Różniła też obu adwersarzy kolejna fundamentalna sprawa - stosunek do Rosji. Piłsudski w czasie Wielkiej Wojny wychodził z założenia, że sprawa polska stanie się przedmiotem prawdziwej debaty międzynarodowej jedynie w przypadku pokonania państwa carów. Natomiast jego stosunek do państw zachodnich zawsze był co najmniej nieufny. I przyznajmy, iż miał w tym zakresie także wiele racji. Chociaż i Dmowski, i Piłsudski stali na stanowisku, że konieczna jest restytucja państwa wielkiego, zdolnego do samodzielnego bytu, to jednak Dmowski uważał, iż spełnienie tego postulatu jest możliwe do pogodzenia z rosyjską racją stanu, a jego rywal wykluczał zdecydowanie taką możliwość ${ }^{25}$.

W ówczesnych realiach geopolitycznych, w obliczu konfrontacji zbrojnej $\mathrm{z}$ bolszewickim państwem rosyjskim, ta sprawa - stosunku do wschodniego sąsiada - zaważyła w sposób decydujący na ostatecznym rozejściu się dróg politycznych obu wielkich Polaków. W realizacji programu wschodniego musiał się więc Piłsudski liczyć z poważnym oporem narodowych demokratów, mających znaczące wspływy nie tylko wśród państw koalicyjnych, lecz także na polskich kresach zachodnich (ziemie byłego zaboru pruskiego), opiniotwórczych i silnych ekonomicznie. Państwa Ententy, chociaż w różnym z stopniu, także były przeciwne budowaniu na wschodnich kresach kontynentu jakieś nowej konfiguracji politycznej, na którą miałby wpływ jedynie niewielki, a która mogła w przyszłości zachwiać ich pozycją polityczną i ekonomiczną $\mathrm{w}$ tym regionie.

Powołanie 16 stycznia 1919 r. rządu Ignacego J. Paderewskiego było wynikiem porozumienia z narodowymi demokratami. Spektakularnym tego skutkiem na forum międzynarodowym stało się oficjalne uznanie rządu polskiego przez mocarstwa zwycięskiej koalicji. Stany Zjednoczone uczyniły to 30 stycznia, Francja 24 lutego, Wielka Brytania 25 lutego, a Włochy 27 lutego $1919 \mathrm{r}$.

${ }^{24}$ R. Dmowski, Myśli nowoczesnego Polaka, Lwów 1904, wyd. II, s. 165, 182.

${ }^{25}$ R. Dmowski, Polityka polska i odbudowanie państwa, t. 1, Warszawa 1988, s. 71-73; T. Komarnicki, dz. cyt., s. 26-27. 


\section{Linia Curzona}

W zwycięskim obozie aliantów w latach 1918-1920 jedynie Francja na ogół zdecydowanie i konsekwentnie przeciwstawiała się militarnie bolszewizmowi, inne kraje europejskie czyniły to dużo bardziej powściągliwie. Fakt ten niezmiernie ułatwiał poczynania Piłsudskiego na wschodzie, zwłaszcza w pierwszej połowie 1919 r. Jednak pozycja Francji systematycznie słabła na korzyść Anglosasów. Już na konferencji pokojowej okazało się, że o bezpośredniej interwencji w Rosji nie może być mowy. Próby Francji zorganizowania przeciw bolszewikom wspólnej skoordynowanej akcji wojskowej spotkały się ze sprzeciwem Wielkiej Brytanii i Stanów Zjednoczonych. Według prezydenta Wilsona, taka akcja mogłaby być „niebezpieczna politycznie i społecznie" 26 . Obawiano się reakcji społeczeństw zachodnich, zmęczonych wojną i będących pod silnym wpływem aktywnej i populistycznej propagandy lewicowej (III Międzynarodówka Komunistyczna, inspirowana przez Lenina i jego towarzyszy). Eksperyment bolszewicki bowiem stał się wśród społeczeństw zachodnich bardzo popularny. Przyznać zatem należy, iż były ku tym obawom pewne uzasadnione podstawy. Posunięto się nawet do tego, że 24 stycznia 1919 r. Rządy Sprzymierzonych wystąpiły z apelem do wszystkich „w Europie i na Wschodzie”, którzy nie czekając na decyzje konferencji pokojowej, starali się zdominować siłą sporne tereny, aby tego zaniechali. Grożono, iż „oparcie suwerenności na gwałcie wyrządzić może odnośnym narodom największą szkodę"27. W rezultacie wszelkie interwencje zbrojne przeciw bolszewikom były nieskoordynowane i o wiele słabsze niż być by mogły. W związku z tym nie osiągnęły nigdy zamierzonego strategicznego celu.

Ententa stanęła więc w obronie interesów rosyjskich, lecz tak naprawdę własnych. Alianci, zwłaszcza Stany Zjednoczone, nie doceniali powagi zagrożenia bolszewickiego, mającego przecież zasięg globalny. Jak wspomniano, zakładano restytucję Polski w granicach etnicznych, licząc na powrót dawnej Rosji na scenę polityczną, po rychłym - jak sądzono - upadku bolszewizmu. W rezultacie, w kalkulacjach politycznych rozważano przede wszystkim punkt widzenia „białych” Rosjan, którego podstawę stanowiła odezwa Rządu Tymczasowego z 30 marca 1917 r., mówiąca o restytucji niepodległej Polski „ze wszystkich ziem zaludnionych w większości przez naród polski”. Zupełnie natomiast zignorowano podstawowe przyczyny problemu.

Ich rozwiązanie rozpocząć należało od unieważnienia traktatów rozbiorowych. Z formalnoprawnego punktu widzenia było to przecież jedyne odniesienie dla określenia terytorium państwa polskiego. Prócz braku dobrej woli,

\footnotetext{
${ }^{26}$ T. Komarnicki, dz. cyt., s. 37.

27 Tamże, s. 38.
} 
wykazano się całkowitą ignorancją dotyczącą przeszłości tych ziem. Wynikały z faktu tego ogromne dla Rzeczypospolitej niekorzystne implikacje prawne i praktyczne. Do czasu podpisania traktatu pokojowego Kresy Wschodnie uważano za czasowo jedynie administrowane przez Polskę tereny dawnego państwa rosyjskiego. W traktacie pokojowym 28 czerwca 1919 r. nie ustalono wschodniej granicy Polski, licząc - jak wspomniano - na restytucję przedbolszewickiej Rosji. W rezultacie ustalono jedynie tzw. linię Curzona, od nazwiska brytyjskiego ministra spraw zagranicznych (notabene George Curzon nie był jej autorem). 8 grudnia 1919 r. ogłoszono deklarację Rady Najwyższej Głównych Mocarstw Sprzymierzonych i Stowarzyszonych, która stała się prawną wykładnią status quo polskiej granicy wschodniej. W zamierzeniu było to jedynie prowizorium rozgraniczające Polskę i Rosję. Tak więc, zgodnie z wcześniejszym traktatem pokojowym, przyznano Polsce podmiotowość prawną na ziemiach położonych na zachód od wyznaczonej linii. Na obszarze tym mogła sprawować władztwo administracyjne ${ }^{28}$.

Termin „linia Curzona” stał się z czasem w historiografii i w publicystyce popularnej swoistym, fałszywie lub tendencyjnie interpretowanym stereotypem i z pewnością wymaga uściślenia oraz wyjaśnienia. Otóż „linia Curzona” była od początku bardzo złym kompromisem, rozwiązaniem nigdy formalnie nieuznanym przez żadną z zainteresowanych stron, ustalonym w okolicznościach wojen o granice toczonych przez państwo restytuujące swoją suwerenność - polsko-ukraińskiej i polsko-bolszewickiej. Do koncepcji powrócono następnie na konferencji w belgijskim Spa (10 lipca 1920 r.). Punktem odniesienia w jej wyznaczeniu była granica trzeciego rozbioru Rzeczypospolitej (1795) oraz granica wschodnia tzw. Królestwa Kongresowego (Królestwo Polskie) z 1815 r. (sic!).

W założeniu była to tylko - co należy z naciskiem podkreślić - linia demarkacyjna, nie zaś granica, która miała obowiązywać do czasu ostatecznego ustalenia granicy polsko-sowieckiej. Dotyczyła początkowo tylko obszarów wchodzących w skład byłego Cesarstwa Rosyjskiego (byłego zaboru rosyjskiego), do punktu, gdzie rzeka Bug przecinała dawną granicę rosyjsko-austriacką (koło Sokala). Natomiast południowy przebieg owej delimitacji wytyczać miał aktualny (początek lipca 1920 r.) przebieg linii frontu polsko-bolszewickiego, czyli rzeka Zbrucz. Do Rzeczypospolitej należeć zatem miała niemal cała Małopolska Wschodnia, m.in. także Lwów. Ostatecznie polską granicę wschodnią, w tym także południowy jej przebieg, na odcinku Galicji Wschodniej, wytyczonej w istocie wzdłuż rzeki Zbrucz, zatwierdzono - jed-

${ }^{28} \mathrm{Na}$ temat konfiguracji politycznej w Europie i relacji aliancko-polskich w roku 1920 wnikliwi i kompetentnie: A. Nowak, Pierwsza zdrada Zachodu: 1920 - zapomniany appeasement, Kraków 2015. 
nakże w wyniku dłuższych negocjacji - dopiero decyzją podjętą przez Radę Ambasadorów z 15 marca 1923 r. ${ }^{29}$

Tzw. linia Curzona przebiegała zatem w ogólnych zarysach od GrodnaNiemirów, przez Białystok-Brześć Litewski-Dorohusk, na wschód od Hrubieszowa przez Kryłów na zachód od Rawy Ruskiej, na wschód od Przemyśla - wzdłuż Zbrucza - w kierunku Karpat; na północ od Grodna wzdłuż linii kolejowej Grodno-Wilno, a następnie w kierunku Dyneburga ${ }^{30}$. Szczegółowy przebieg linii Curzona, zwłaszcza południowy jej odcinek, budził jednakże od samego początku wiele kontrowersji, wynikających przede wszystkim z tendencyjnego interpretowania ustaleń przez stronę sowiecką. Linia Curzona stała się w latach 1943-1945 podstawą do wytyczenia przez aliantów współczesnej wschodniej granicy Rzeczypospolitej. Sowieci ignorowali $\mathrm{w}$ ten sposób wszelkie ustalenia związane z granicą ryską. Najbardziej istotne były spotkania przywódców, one bowiem wytyczały zasadnicze kierunki działań. W ostatnim dniu konferencji teherańskiej (28 listopada - 1 grudnia 1943 r.) omawiano sprawy Polski. Wstępnie przyjęto przebieg jej wschodniej granicy w oparciu o linię Curzona i zasadę rekompensaty terytorialnej na zachodzie kosztem Niemiec. Dalsze uzgodnienia przyjęto podczas konferencji jałtańskiej w lutym $1945 \mathrm{r}$.

Pozostał zatem nierozwiązany problem statusu ziem położonych na wschód od „linii Curzona”, w więc także ziem byłego Wielkiego Księstwa Litewskiego. Wobec nieprzychylnego stanowiska aliantów Piłsudski przyjął jedyną i bez wątpienia najskuteczniejszą metodę postępowania - działania na drodze faktów dokonanych. W czasie rozmowy z premierem Ignacym Paderewskim, przed jego wjazdem na konferencję pokojową, nie ukrywał swoich zamiarów wobec ziem położonych za Bugiem. „[...] Z panem Paderewskim byliśmy zgodni pod jednym względem - pod względem przeszkód jakie na drodze spotkamy. Przeszkody te tkwią w poglądach świata, który jest przeciwko nam. Pojęcia świata bowiem układane były na podstawie niedawnej przeszłości, która była przeciwko nam i która mówiła języ-

${ }^{29}$ Tzw. linia Curzona została nazwana od nazwiska angielskiego dyplomaty George'a Curzona, ministra spraw zagranicznych w rządzie premiera Davida Lloyda George'a. W okresie konferencji wersalskiej dochodziło do częstej różnicy zdań pomiędzy brytyjskim premierem a jego ministrem spraw zagranicznych, który nie miał większego wpływu na przebieg ówczesnych decyzji. Tzw. linia Curzona była w istocie „linią Lloyda George'a”.

${ }^{30}$ Instytut Polski i Muzeum im. gen. Sikorskiego, Ministerstwo Prac Kongresowych (IPMS), sygn. A.21.11. Opracowanie Stanisława Skrzypka z lipca 1944 r. w sprawie tzw. linii Curzona. W czasie obrad Rady Sprzymierzonych i jej komisji do spraw polskich w latach 1918-1919 nigdy nie było brane pod uwagę przyłączenia Małopolski Wschodniej do Rosji. Kraj ten w ciągu swych dziejów nigdy do państwa rosyjskiego nie należał. Proponowane w roku 1919 rozwiązania szły w kierunku albo utworzenia z Galicji Wschodniej kraju autonomicznego pod suwerennością Polski, albo też, gdyby miało dojść do powołania niepodległego państwa ukraińskiego, przewidywały pozostawienie Lwowa przy Polsce. 
kiem oficjalnym, że przekroczenie Bugu - to aneksja. Z powodu tej właśnie przeszłości utrudniającym momentem były zobowiązania wobec Rosji, które miały wielkie mocarstwa z tytułu przymierza i dzięki wspólnym z Rosją trudom, poniesionym $\mathrm{w}$ wielkiej wojnie. Pod tym względem byliśmy z panem Paderewskim zgodni. Natomiast co do środków przezwyciężenia lub obejścia trudności byliśmy rozbieżni. Ja kładłem nacisk na siłę stworzenia faktów dokonanych $[\ldots]^{\prime \prime 31}$. Natomiast premier Paderewski liczył na poparcie Stanów Zjednoczonych i prezydenta Wilsona, z którym był w osobistych, dobrych relacjach. Jego rachuby i tym razem okazały się jedynie myśleniem życzeniowym. Paderewski mylił uprzejmość okazywaną jego osobie z akceptacją dla polskiej polityki, w szczególności tej wschodniej. Poparcie zza Oceanu bowiem było chwiejne, a przede wszystkim niedostateczne ${ }^{32}$.

Realizując swoje zamiary, nie używał nawet określenia „federacja”. Wyjaśnił to w kilka lat później: „,[...] federacji nie da się zastosować na tych ziemiach $[\ldots]$ nie widziałem tutaj tych, którzy by do tej federacji chcieli przystąpić $[\ldots]^{\prime \prime 3}$. Uważał bowiem słusznie, że Litwa, rozumiana jako nowy byt polityczny, bo o niej mówił, odwróciła się od Polski, trudno zatem współpracować z kimś, kto tego nie chce. Wybrał zatem drogę okrężną, lecz prowadzącą do tego samego celu. Zaczął tworzyć fakty dokonane i dążyć następnie do ich prawnego uznania międzynarodowego. Wybory i powołanie rządu w Wilnie - to była właśnie droga Naczelnika Państwa. Przedtem jednak należało stworzyć w mieście Giedymina możliwość podejmowania decyzji politycznych. Stąd wziął się zamysł operacji wileńskiej, opanowania Wilna orężnie. Jednak pierwszą kwestię, którą podjął na drodze faktów dokonanych - zbrojnie - była przynależność do Polski Małopolski Wschodniej. Odbyło się to wbrew stanowisku Wielkiej Brytanii, a z przychylnością Francji. Walki o Galicję trwały od listopada 1918 do lipca 1919 r. Ich efekty były dla Rzeczypospolitej satysfakcjonujące. Zdecydowana postawa Naczelnika spotkała się z poparciem społecznym. Do zwycięstwa przyczyniło się też przybycie z Francji, wiosną 1919 r., Armii Polskiej dowodzonej przez gen. Józefa Hallera („Błękitna Armia”) oraz zdeterminowane działania dyplomatyczne polskiej delegacji na forum paryskiej konferencji pokojowej. Wewnętrzna spójność przyniosła efekty ${ }^{34}$.

Tak więc polityka mocarstw wobec Polski była jedynie funkcją ich stosunku do Rosji i Niemiec. Stawiało to Polskę, u zarania jej nowego bytu po-

${ }^{31}$ J. Piłsudski, Pisma, t. 6, s. 121-122. „Sprawa wileńska”, wykład wygłoszony 24 sierpnia 1923 r. w sali wileńskiego Teatru Wielkiego.

${ }^{32} \mathrm{G}$. Łukomski, Ambasador polskości, [w:] Geniusz przypadkowo grający na fortepianie. Ignacy Jan Paderewski 1860-1941, Poznań 2001, s. 13-23.

33 J. Piłsudski, Pisma, t. 6, s. 122 („Sprawa wileńska”).

${ }^{34}$ T. Komarnicki, dz. cyt., s. 38-42. Szczegółowa analiza tej problematyki przekracza zakres merytoryczny pracy. 
litycznego, w niezmiernie trudnych warunkach, zwłaszcza w zakresie walki o własne granice. W tym szczególnie wschodnie rubieże państwa. Polska jako w pełni samodzielny podmiot polityczny nie mieściła się w ówczesnej konfiguracji europejskiej, a nawet $w$ mentalności polityków. $Z$ ich punktu widzenia była państwem nowym, tworzonym niejako z nadania swoich protektorów. Chociaż wiedza historyczna polityków zachodnich nie była zbyt głęboka (o czym wielokrotnie wspominali polscy eksperci na konferencję pokojową), to jednak pamiętano, iż Rzeczpospolita wypadła z gry jeszcze w XVIII stuleciu, a wytworzoną wówczas próżnię zajęli inni. Rzecz jasna, nikt w XX w. nie zamierzał przywracać Polakom ich kraju w granicach sprzed rozbiorów. Powrót bowiem do status quo ante oznaczałby umniejszenie własnych wpływów. Przecież konferencja pokojowa nie była spotkaniem towarzyskim ani też towarzystwem charytatywnym, lecz forum twardej, bezkompromisowej gry politycznej. Z perspektywy lat Lloyd George bardzo szczerze określił polskie aspiracje na konferencji: „[...] Nikt nie sprawił większego kłopotu niż Polacy. Upojona młodym winem wolności, dostarczonym przez aliantów, Polska wyobrażała sobie, że jest znów panią losów Europy[...]"35.

I jako podsumowanie, posłużmy się refleksją ogólniejszej, lecz i nieco lżejszej natury. Otóż w 1517 r. Maciej Miechowita, polski pisarz, historyk, geograf, także profesor Akademii Krakowskiej, opublikował dzieło zatytułowane Traktat o dwóch Sarmacjach... (polskie tłumaczenie z 1535 r.). W nawiązaniu do tytułu powyższej pracy Wiktor Sukiennicki, godny najwyższego szacunku znawca problematyki Wielkiego Księstwa Litewskiego, w swym znakomicie napisanym, błyskotliwym eseju zauważył: „,...] Gdyby nasi przodkowie z XVI i następnych wieków nie dopuścili się tak brzemiennego w złowrogie konsekwencje błędu semantycznego [ma na myśli unię lubelską $1569 \mathrm{r}$. i określenie, które w jej konsekwencji upowszechniło się jako nazwa państwa: Rzeczpospolita Obojga Narodów -G.Ł.], gdyby poszli za sugestią Miechowity, albo wymyślili jakąś inną nazwę - analogiczną do »Wielkiej Brytanii «, "Stanów Zjednoczonych", etc. - w rodzaju »Stanów Zjednoczonych Europy Wschodniej«,»ZwiązkuWschodniego«, czy »Międzymorza«(»Intermarium«), porozumienie w XX wieku pomiędzy brytyjskim Walijczykiem [Davidem Lloydem George'em - G.Ł.], a polskim »Ukraińcem « [Ignacy Jan Paderewski G.Ł.] czy »Litwinem « [Józef Piłsudski - G.Ł.] byłoby równie łatwe, jak objęcie przez Walijczyka stanowiska brytyjskiego (nie angielskiego) premiera czy objęcie prezydentury »Międzymorza « (»Intermarium«), (a nie państwa polskiego) przez Ukraińca czy Litwina [... $]^{\prime 36}$. Tak, trudna i skomplikowana teraźniejszość wynikała z sumy błędów popełnionych przez antenatów.

${ }^{35}$ D. Lloyd George, Prawda o traktacie wersalskim, tł. Antoni Pański t. 1, Warszawa 1939, s. 277-278.

${ }^{36}$ W. Sukiennicki, dz. cyt., s. 33. 


\section{Bibliografia}

\section{Źródła archiwalne}

Instytut Polski i Muzeum im. gen. Sikorskiego w Londynie (IPMS), Ministerstwo Prac Kongresowych, sygn. A. 21.11.

\section{Źródła drukowane}

Baranowski W., Rozmowy z Pitsudskim 1916-1931, Warszawa 1938.

Brandenburg E., Deutschlands Kreiegsziele, Leipzig 1917.

Dmowski R., Myśli nowoczesnego Polaka, Lwów 1904, wyd. II.

Dmowski R., Polityka polska i odbudowanie państwa, t. 1, Warszawa 1988.

Dmowski R., Polityka polska i odbudowanie państwa, t. 2, Warszawa 1988.

Lloyd George L., Prawda o traktacie wersalskim, tł. Antoni Pański t. 1, Warszawa 1939.

Meysztowicz W., Gawędy o czasach i ludziach, Londyn 1993, wyd. IV.

Miłosz Cz., Szukanie ojczyzny, Kraków 2001.

Naumann F., Mitteleuropa, Berlin, październik 1915.

Piłsudski J., Pisma zbiorowe, Wydanie prac dotychczas drukiem ogłoszonych, t. 5, Warszawa 1937.

Piłsudski J., Pisma zbiorowe, Wydanie prac dotychczas drukiem ogłoszonych, t. 6, Warszawa 1937.

Sokolnicki M., W stużbie Komendanta, „Kultura” Paryż 1953, nr 74.

\section{Opracowania}

Cienciała A., Stosunki polsko-sowieckie - federalizm - polityka polska - 1914-1921, „Zeszyty Historyczne" Paryż 1970, z. 18.

Karski J., Wielkie mocarstwa wobec Polski 1919-1945. Od Wersalu do Jatty, Lublin 1998.

Komarnicki T., Piłsudski a polityka wielkich mocarstw, "Niepodległość” Londyn 1952, t. 4 (po wznowieniu).

Lundgreen-Nielsen K., The Polish Problem at the Paris Peace Conference. A Study of Policies of the Great Powers and the Poles, 1918-1919, przekł. A. Borch-Johansen, Odense University Press 1979.

Łossowski P., Między wojna a pokojem. Niemieckie zamysty wojenne na wschodzie w obliczu traktatu wersalskiego, marzec-czerwiec 1919 roku, Warszawa 1976.

Łukomski G., Ambasador polskości, [w:] Geniusz przypadkowo grajacy na fortepianie. Ignacy Jan Paderewski 1860-1941, Poznań 2001.

Łukomski G., Polityczna przestrzeń polskości w XX wieku Bezpieczeństwo polityczne Rzeczypospolitej z perspektywy racji stanu, Poznań-Londyn 2013.

Łukomski G., Problem „korytarza” w stosunkach polsko-niemieckich i na arenie międzynarodowej 19191939. Studium polityczne, Warszawa 2000.

Mackiewicz (Cat) S., Historia Polski od 11 listopada 1918 r. do 17 września 1939 r., Warszawa 1989.

Nowak A., Pierwsza zdrada Zachodu: 1920 - zapomniany appeasement, Kraków 2015.

Okulicz K., Brzask, dzień i zmierzch na ziemiach Litwy Historycznej, [w:] Pamiętnik Wileński, Londyn 1972.

Piotrowski B., Badania nad Polska i krajami nadbałtyckimi na Uniwersytecie Królewieckim (19161932), „Komunikaty Instytutu Bałtyckiego” Gdańsk 1983, z. 35.

Ruecker E., Marski T., Instytuty naukowe w Niemczech w stużbie propagandy, [w:] Przeciw propagandzie korytarzowej, red. J. Borowik, Torun 1930.

Sukiennicki W., East Central Europe during World War I: from Foreign Domination to National Independence, vol. I, New York 1984.

Sukiennicki W., Polityczne konsekwencje błędu semantycznego, „Zeszyty Historyczne” Paryż 1985, z. 72 . 


\title{
Grzegorz Łukomski
}

\section{Ententa i Niemcy wobec polskiej polityki wschodniej 1918-1919}

\section{Streszczenie}

Podjęto problem stosunku państw Ententy do kwestii restytucji państwa polskiego w latach 19181919. Przeanalizowano relacje twórców Rzeczypospolitej, szczególnie Romana Dmowskiego, Józefa Piłsudskiego oraz Ignacego Jana Paderewskiego, z Wielką Brytanią, Francją i Stanami Zjednoczonymi, kluczowymi partnerami i graczami politycznymi w okresie paryskiej konferencji pokojowej (1919 r.). Na relacje powyższe długi cień rzucały stosunki Ententy z pokonanymi Niemcami oraz - w równym stopniu - z „białą” i bolszewicką Rosją. Państwa Ententy dbały przede wszystkim o zachowanie i poszerzenie swoich wpływów w Europie Środkowej i Wschodniej. Bardzo ważne były też interesy niemieckie i niemiecka Ostpolitik w tym regionie Europy, prowadzona konsekwentnie od schyłku XIX w.

Tak więc polityka mocarstw wobec Polski była jedynie funkcją ich stosunku do Rosji i Niemiec. Stawiało to Polskę, u zarania jej nowego bytu politycznego, w niezmiernie trudnych warunkach, zwłaszcza w zakresie walki o granice. W tym szczególnie wschodnie rubieże państwa. Polska jako $\mathrm{w}$ pełni samodzielny podmiot polityczny nie mieściła się w ówczesnej konfiguracji europejskiej, a nawet w mentalności polityków, zwłaszcza brytyjskich, myślących kategoriami kolonialnymi. $Z$ ich punktu widzenia była państwem nowym, tworzonym niejako z nadania swoich protektorów. Jedynie Francja i w niepełnym zakresie Stany Zjednoczone traktowały Polskę jako samodzielny oraz suwerenny byt polityczny.

Dla Niemiec możliwe było istnienie Polski jedynie jako państwa buforowego, kadłubowego i niesuwerennego, które byłoby łatwym terenem penetracji i eksploatacji.

Słowa kluczowe: Ententa, Niemcy, Ostpolitik, restytucja państwa, linia Curzona, polityka polska, polityka międzynarodowa, Kresy Wschodnie, Piłsudski Józef, Paderewski Ignacy J., Dmowski Roman

\section{The attitude of the Triple Entente and Germany towards Polish eastern policy in the years 1918-1919}

\begin{abstract}
The article discusses the problem of the attitude of the Tripe Entente states towards the restoration of Poland in the years 1918-1919. Relations between the creators of the Republic of Poland (in particular Roman Dmowski, Józef Piłsudski, and Ignacy Jan Paderewski) and Great Britain, France and the USA - the key partners and political players in the period of the Paris Peace Conference (1919) - were analyzed. Those were greatly affected by the relations between those states and the defeated Germany, as well as "White" and Bolshevik Russia. The Triple Entente cared mainly about maintaining and expanding their influence in Central and Eastern Europe. Also, of major significance were the German interests and Ostpolitik in this region of Europe, consistently implemented from the late $19^{\text {th }}$ century.

Therefore, the policy of the world powers towards Poland was indirectly affected by their attitudes towards Russia and Germany. In the early days of Poland's political existence, it put Poland in an extremely difficult situation, especially when fighting for its borders, in particular in the east. Poland, as a fully independent political entity, did not fit in the European model of the time - even in the minds of politicians, especially British, who were still thinking in co-
\end{abstract}


lonial categories. From their point of view, Poland was a new state, created upon the will of its protectors. Only France and, to some extent, the United States treated Poland as an independent and sovereign political entity.

For Germany, Poland could exist only as a buffer, rump, non-sovereign state, which would be easy to invade and exploit.

Key words: Triple Entente, Germany, Ostpolitik, state restoration, Curzon Line, Polish policy, international policy, Eastern Borderlands, Piłsudski Józef, Paderewski Ignacy J., Dmowski Roman 